Crime, Histoire \& Sociétés / Crime, History \& Societies

Vol. 21, $n^{\circ} 2$ | 2017

L'histoire de la criminalité et de la justice pénale : propositions de recherche pour le $21^{\mathrm{e}}$ siècle

\title{
Homicide Rates and Mortality Trends: Perspectives from Public-Health Scholarship
}

Jeffrey S. Adler

\section{(2) OpenEdition \\ Journals}

Electronic version

URL: http://journals.openedition.org/chs/2025

DOI: $10.4000 /$ chs. 2025

ISSN: 1663-4837

\section{Publisher}

Librairie Droz

\section{Printed version}

Date of publication: 31 December 2017

Number of pages: $343-350$

ISSN: $1422-0857$

Electronic reference

Jeffrey S. Adler, "Homicide Rates and Mortality Trends: Perspectives from Public-Health Scholarship", Crime, Histoire \& Sociétés / Crime, History \& Societies [Online], Vol. 21, n² I 2017, Online since 19 July 2020, connection on 15 January 2021. URL: http://journals.openedition.org/chs/2025 ; DOI: https:// doi.org/10.4000/chs.2025 


\title{
Homicide Rates and Mortality Trends: Perspectives from Public-Health Scholarship
}

\author{
Jeffrey S. Adler
}

$\mathrm{M}$ ore than three decades ago, Eric H. Monkkonen celebrated the creative fragmentation of criminal-justice history ${ }^{1}$. He compared the field, which was then in its infancy, to U.S. urban history and noted that the latter had quickly become inward-looking as a consequence of a rush to synthesize exciting new findings. The great methodological and theoretical promise of 1960s and 1970s urban mobility studies dominated the field, making it increasingly narrow as historian after historian reproduced the core approaches and perspectives. By contrast, according to Monkkonen, criminal justice history remained dynamic, adapting methods and theories from a wide range of disciplines and examining a broad spectrum of themes. Historians of crime, for example, employed both qualitative and quantitative methods and published their work in disparate publication outlets within subfields of history and across myriad disciplinary lines.

The years since Monkkonen's jeremiad have confirmed his judgment. The field's intellectual diversity and disciplinary fragmentation have yielded rich, innovative scholarship. Resisting methodological and theoretical orthodoxies, criminal justice historians have continued to embrace new approaches, challenge the conventional wisdom, ask novel questions, draw from wide-ranging theoretical perspectives, and publish in journals scattered across the scholarly landscape. My own work on the history of crime in the United States, for instance, has borrowed from fields ranging from evolutionary psychology to neurophysiology and has appeared in legal, criminology, sociology, and history journals as well as in books published by university presses.

Such intellectual and disciplinary diversity notwithstanding, much of the scholarship in the field has drawn from the social sciences - particularly sociology, criminology, and social psychology - or from literary theory and cultural analysis. Historians of violence, for example, have made especially effective use of methodological approaches and theoretical frameworks pioneered by social scientists, such as Norbert Elias, Roger Gould, Marvin Wolfgang, Gary LaFree, and Martin Daly and Margo Wilson ${ }^{2}$. Constructing massive, detailed data sets using case-level sources, historians of homicide have analyzed who committed illegal acts, who were the victims, and how these patterns changed over time ${ }^{3}$. Their studies have identified the demographic backgrounds of those involved in crime and the social and cultural triggers for criminal violence, all the while charting shifts across space and over time.

Monkkonen (1986, p.1146-1157).

Elias (1939, repr, 1994); Gould (2003); Wolfgang (1958); LaFree (1998); Daly and Wilson (1988).

For example, see Monkkonen (2001); Adler (2006); Roth (2009).

Crime, Histoire \& Sociétés / Crime, History \& Societies 2017, vol. 21 , n² 2, pp. 343-350. 
Recent scholarship from another corner of the academic world, however, holds additional promise for criminal-justice historians, not to replace established frameworks but to supplement and complement them. Research from public-health economists and demographers offers particularly important, fresh insights for historians of crime. Rather than relying on the case-level research more commonly employed by social historians of crime, public-health scholarship typically focuses on macro-level analyses, and therefore these studies can suggest perspectives and explanations beyond our usual ken. One example, drawn from my current research, may illustrate the potential contribution from public-health scholarship.

Trends in American violent crime during the interwar period, particularly the 1930s, have puzzled historians. The homicide rate in the United States surged during the 1920 s, rising by 17.9 percent $^{4}$. The increase in lethal violence was especially pronounced early in the decade and in major urban centers. Between 1920 and 1925, for instance, Chicago's homicide rate jumped by 94.8 percent, New Orleans's by 132.7 percent, St. Louis's by 57.1 percent, Detroit's by 42.0 percent, Baltimore's by 60.0 percent, and Rochester's by 94.1 percent $^{5}$. In most American cities, the rate of such violence peaked during the mid-to-late 1920s.

A blend of demographic, cultural, and social forces likely accounted for the sharp rise in homicide during the 1920s. The return of soldiers after World War One and high levels of migration, especially by African American fleeing the South and resettling in the industrial centers of the American North, produced imbalanced sex ratios, roiled domestic relations, fueled racism, and contributed to social turmoil, which sometimes turned violent. Prohibition and the expansion of criminal networks added to the death toll as well, though popular culture has wildly exaggerated this source of violence ${ }^{6}$.

Far more perplexing for criminal-justice historians, however, are the 1930s, for American homicide (as well as lethal violence in much of western Europe) plummeted during the Great Depression. Between 1929, when the U.S. stock-market crash triggered the economic crisis, and 1940, the American homicide rate plunged by 29.5 percent, despite the skyrocketing unemployment rates and soaring levels of poverty? In U.S. cities, lethal violence fell even more dramatically. Chicago's homicide rate dipped by 33.1 percent, Detroit's by 66.3 percent, New Orleans's by 56.6 percent, New York City's by 41.8 percent, Pittsburgh's by 61.0 percent, and Birmingham's by 46.0 percent. For the interwar period, lethal violence hit its low-water mark in 1939 or 1940 in Chicago, Detroit, New Orleans, Memphis, Birmingham, New York City, and many other cities, even though roughly one-sixth of workers remained unemployed ${ }^{8}$.

Such a trend confounds our understanding of the triggers for violence. Social scientists typically associate poverty with increasing social conflict, welling group

Eckberg (2006, p.239).

The homicide and mortality rate data discussed in this essay, unless otherwise noted, comes from the U.S. government's annual publication of the Vital Statistics of the United States: Mortality Statistics, 21-41 (1922-1943).

6 Boudouris (1974, p.532); Monkkonen (2001, p.203).

Eckberg (2006, p.239).

8 Hosen (1992, p.257). 
tensions, and rising levels of family turmoil ${ }^{9}$. Yet, during the deepest, longest economic crisis in U.S. history, lethal violence spiraled downward.

Historians have noted but not explained this counter-intuitive pattern, in which violence soared during the prosperous 1920s and then plunged during the Great Depression $^{10}$. The 1930 s trend is, needless to say, particularly vexing. Just as gangland violence did not account for the increase in lethal violence, the end of Prohibition did not produce the huge dip in homicide during the Great Depression, for the drop in homicide began long before the repeal of the Eighteenth Amendment to the U.S. Constitution in 1933.

Two scholars have recently attempted to make sense of the surprising relationship between American violence and the Great Depression. The criminologist Barry Latzer describes the sharp fall in homicide during the 1930s and speculates that perhaps the surge in poverty simply exerted little effect on violent behavior, which is typically "unaffected by economic downturns or upswings." 11 But he also observes that homicide rates tumbled during other hard times, such as the 1890s, and soared during prosperous decades, including the 1920s and the 1960s ${ }^{12}$. The historian Randolph Roth offers a provocative explanation for the drop in American violence during the Great Depression. Roth suggests that Franklin Delano Roosevelt's calming influence re-established confidence in government and the legitimacy of the social order, which, in turn, tamped down lethal violence ${ }^{13}$. In most American cities, however, homicide rates began to fall many years before 1933, when FDR became president. Between 1929, when the Great Depression began, and 1933, New Orleans's homicide rate had already plunged by 34.8 percent, Detroit's by 31.9 percent, Baltimore's by 22.3 percent, and Philadelphia's by 23.9 percent. Moreover, the drop in African American homicide accounted for the lion's share of the overall decrease in the level of violence in cities such as New Orleans ${ }^{14}$. Yet increasingly oppressive Jim Crow measures had nearly completely disfranchised African American New Orleanians; only 0.8 percent were registered to vote when Roosevelt entered the White House, and by 1940 the figure had fallen to 0.3 percent, making it unlikely that the president's "Fireside Chats" restored African Americans' "faith in the country" and hence reduced lethal violence in the city ${ }^{15}$.

If not the soothing voice of Roosevelt, why did homicide plummet in the United States during the Great Depression? Case-level data provide no obvious explanations. To the contrary, a statistical analysis of killers and victims during the interwar period reveals little change; the same kinds of people committed (and were victims of)

For example, see Fishback et al. (2007, p.10); Stansfield et al. (2017, p.61).

10 Gurr (1989, p.41-43); Loftin et al. (1989, p.171); Zahn (1989, p.219-22); Monkkonen (2001, p.17); Lane (1997, p.248).

11 Latzer (2014).

12 Latzer (2016, p.44).

13 Roth (2009, p.440-441).

14 The figures and descriptions of homicide in New Orleans come from my data set, compiled from police and coroners reports on every New Orleans homicide, court records, penitentiary files, newspaper accounts of crime, and other sources. The data set includes 2118 cases.

15 Roth (2009, p.441); Tyler (1996, p.28). Nor would Roosevelt's calming words explain the 1930s drop in homicide in much of western Europe. 
lethal violence during the flush years of the 1920s and during the deep depression of the 1930s. New Orleans data illustrates this continuity ${ }^{16}$. The city's homicide rate tumbled by more than half from 1929 until 1940. Between the good times of the 1920s and the lean years of the Great Depression, the proportion of killers who were African American changed by less than 1 percent; the proportion of victims who were African American varied by less than 2 percent; the proportion of killers with low-blue-collar jobs fluctuated by 3 percent; the proportion of killers who were men shifted by 3 percent; the percentage of homicides occurring in the home changed by less than 1 percent; and the proportion of assailants who killed acquaintances varied by 1 percent. Simply put, while the rate of lethal violence plunged, roughly the same people in the same settings killed, though they did so significantly less often than before. Why, then, did American violence drop as the U.S. economy tanked?

Public-health researchers have explored these paradoxical patterns and have shed intriguing light on the steep rise and then sharp fall in American homicide during the interwar period. In analyzing the effects of short-term economic changes on mortality trends, these economists and demographers have discovered that lethal violence tends to be "procyclical." In other words, homicide typically rises when the economy grows and falls when it contracts ${ }^{17}$.

But homicide rates, according to these researchers, did not shift in isolation. Rather, lethal violence varied with overall mortality, which is also procyclical. Death rates, including homicide rates, tend to increase in good economic times and decrease during hard times. When labor markets tighten, mortality rises, while death rates for eight of the ten leading causes of mortality decrease when labor markets languish ${ }^{18}$. One study concluded that a "one point increase in unemployment reduces predicted mortality from motor vehicle crashes, other accidents, and homicides by 3.0, 1.6, and 1.9 percent respectively" 19 . Early twentieth-century demographic data confirm this counter-intuitive pattern. During the Great Depression Americans were healthier, lived longer, grew taller, and less often died from disease, accidents, and homicide than during the flush times of the previous decade. Between 1929 and 1940, the U.S. unemployment rate leaped by 356.3 percent, and from 1931 to 1940 it never dipped below 14.3 percent $^{20}$. Yet life expectancy climbed by 5.8 years $^{21}$. During the worst years of the depression, the proportion of Americans with annual incomes below $\$ 150$ nearly quadrupled, though life expectancy jumped by more than five years ${ }^{22}$. The height of men reaching maturity rose by almost two centimeters during the $1930 \mathrm{~s}^{23}$.

Urban mortality data for the 1930s provide additional evidence. Homicides, which comprised roughly 1 percent of all deaths in American cities during the Great Depression, fell more sharply than overall mortality but followed precisely the same

\footnotetext{
16 No city was "representative" of national trends, though New Orleans followed the same trends as other major urban centers and similar patterns as the nation overall.

17 Ruhm (2000, p.632); Ruhm (2005, p.341); Granados (2005, p.1195-1196); Adda et al.(2009, p.1386).

18 Ruhm (2000, p.617); Gerdthman and Ruhm (2006, p.299).

19 Ruhm (2000, p.632). The two outliers are suicide and cancer.

20 Hosen (1992, p.257).

21 Hosen (1992, p.252).

22 Perrott and Collins (1934, p.219); Granados and Diex Roux, (2009, p.17290).

23. Fogel (2004, p.37).
} 
trend. Between 1929 and 1940, Detroit's homicide rate plunged by two-thirds, while the city's mortality rate fell by 23.9 percent. In New York City, homicide dropped by nearly half and mortality by 10 percent, and in Memphis, the lethal violence rate dipped by 55.5 percent, while mortality fell by 21.7 percent. In short, the decreasing rate of homicide during the Great Depression occurred as a part of a wider, larger drop in death rates, suggesting that the dip in lethal violence was somehow related to the fall in mortality from other causes ${ }^{24}$.

Public-health researchers recognize that correlation is not causation, and they do not argue that people lived longer, grew taller, became healthier, and butchered one another less frequently because they were suddenly penniless, jobless, and homeless ${ }^{25}$. Nonetheless, such sustained procyclicality, supported by an analysis of interwar death rates but also nearly a century of data, suggests that changes in overall mortality rates might offer clues about fluctuations in homicide rates ${ }^{26}$.

Armed with considerable quantitative evidence supporting their procyclicality model, economists and demographers speculate that spikes in poverty and short-term surges in unemployment change peoples' lifestyles in ways that reduce myriad forms of premature death, including homicide ${ }^{27}$. Numerous studies demonstrate that alcohol consumption, particularly by heavy drinkers, rises in good times and falls when the economy falters and people have less money to spend on beer and whiskey ${ }^{28}$. Data on cirrhosis deaths support this view ${ }^{29}$. In New Orleans between 1920 and 1929, despite Prohibition, the city's cirrhosis death rate rose by 25.1 percent. Yet from 1929 to 1940, the rate fell by 34.7 percent, even though Prohibition ended in 1933. Inebriation was also a contributing factor to a wide variety of violent crimes, ranging from saloon brawls to wife beating. Thus, the public-health scholarship on alcohol consumption and economic change may help to explain the spike in homicide during the booming 1920s and the drop during the 1930s.

Closely related, the dearth of disposable income during the Great Depression probably discouraged raucous leisure activities. Street life likely became quieter, and, in fact, lethal violence on the streets of New Orleans plunged by 49.9 percent between 1929 and 1940. Similarly, motor-vehicle deaths decrease when the economy contracts. People drive less and are less likely to drive while intoxicated, as recently scholarship has noted ${ }^{30}$. In New Orleans, the automobile-fatality rate dropped by 28.0 percent during the Great Depression. Other forms of accidental death follow (and followed) the same pattern. Between 1929 and 1940, the rate of (non-vehicular) accidental death fell by 29.9 percent in New Orleans. During hard times people appear to be more

\footnotetext{
24 No shifts in medical treatment or trauma care account for this pattern.

25 Gerdtham and Ruhm (2006, p.314).

26 Granados (2005, p.1196); Ruhm (2015). In some ways, the historian Roger Lane's insightful analysis of violent death in nineteenth-century Philadelphia anticipated such a pattern. See Lane (1979).

27 Ruhm (2005, p.1209); Lin et al. (1995, p.531); Adda et al. (2009, p.1391).

28 Lin et al. (1995, p.535); Granados and Diex Roux (2009, p.17293); Ruhm (2005, p.1209); Ruhm and Black (2002, p.660).

29 To be sure, cirrhosis death rates offer an imperfect measure of alcohol consumption, though the pattern is revealing and consistent with more precise recent studies of the effects of economic forces on drinking.

30 Ruhm (2000, p. 621); Ruhm and Black (2002, p. 660); Gerdtham and Ruhm (2006, p. 301); Lin et al. (1995, p. 535).
} 
cautious, drowning, falling off balconies, and tumbling down stairs less frequently.

Migration is also sensitive to economic trends and procyclical ${ }^{31}$. Compared with the boom times of the 1920s, the flow of newcomers to American cities dropped sharply during the 1930s. As a consequence, crowding decreased, sex ratios balanced and the proportion of young, single men - the group most responsible for lethal violence - contracted in American urban centers. Older and more stable populations proved to be less volatile and less homicidal as migration waned.

If Americans had little disposable income to spend on leisure activities, socializing, and consumer goods, perhaps this affected the way that they resolved conflict, and perhaps it influenced violent death just as it altered trends in accidental death and overall mortality. As they became relatively poorer during the Great Depression, Americans appear to have used firearms less than during the 1920s, for gun violence in interwar America was procyclical. It surged when the economy expanded and plummeted when it contracted. During the 1920s, firearms violence exploded. But, with the high rates of poverty and unemployment after 1929 and therefore less disposable income, poorer Americans may have been less able to afford guns, just as they were less able to purchase alcohol and automobiles. Scattered evidence suggests that handguns became more expensive during the 1930s, when income fell ${ }^{32}$. It seems plausible that fewer people, particularly young and poor Americans, could afford these weapons, and quantitative evidence provides strong evidence of such a procyclical shift. Gun homicide in the United States dropped precipitously during the Great Depression ${ }^{33}$. New Orleans sources permit a fine-grained analysis of this change. During the flush 1920s, the city's firearm homicide rate leaped by 45.3 percent, whereas it fell by 64.1 percent during the Great Depression. In fact, the drop in gun homicide accounted for nearly all of the decrease in New Orleans's homicide rate during the 1929-1940 period. Furthermore the variance in gun homicide, like the fluctuations in overall mortality in the city, was particularly pronounced among African American residents, who committed two-thirds of local homicides. During the 1920s, the African American firearm homicide rate soared by 191.9 percent. But, from the start of the depression until the eve of World War I, New Orleans's African American gun homicide rate plunged by 80.8 percent, tracking race-based changes in overall mortality rates.

In short, economic trends correlated with patterns of overall mortality rates and with shifts in gun violence in interwar America, suggesting that the hard times that reduced drinking, driving, and other high-risk behavior may have limited access to firearms, contributing to the drop in lethal violence that paralleled the fall in the rate of accidental death and alcohol-related mortality. Even if the same kinds of people in the same sorts of social circumstances killed in the 1930s as in the 1920s, during the Great Depression violence less often involved firearms and hence the rate of lethality dropped, as broken noses, cracked ribs, and knife injuries replaced deadly gunshot wounds. The economic crisis of the 1930s, in other words, may have indirectly reduced early death - from disease and accidents but also from homicide.

\footnotetext{
31 Ruhm (2000, p.619).

32 New Orleans police larceny reports indicate that the value of handguns stolen during the 1930s was significantly higher than the comparable figure for the 1920s. Such data is not definitive, though it is suggestive.

33 Wintemute (1987, p.533).
} 
With its focus on wider, macro-level trends, public-health scholarship may help to explain shifts in crime that can be obscured or masked by case-level data analysis. Thus, the combination of a public-health approach to lethal violence and the more familiar methods employed by criminal justice historians may shed light on the mysterious drop in homicide during the Great Depression - and changes in crime during other upswings and downturns in the economy. Likewise, public-health scholarship on the long-term effects of exposure to violence or on the biochemical impact of stress or on the impact of "community efficacy" on the ecology of violence could provide historians with fresh approaches to a wide range of research questions. Sometimes criminal-justice historians can find new insights in unlikely places, such as the International Journal of Epidemiology.

\author{
Jeffrey S. Adler \\ Department of History \\ University of Florida \\ P.O. Box 117320 \\ Gainesville, FL 32611-7320 \\ jadler@ufl.edu
}

\title{
BIBLIOGRAPHY
}

Adda, J., Banks, J. and von Gaudecker, H.-M. (2009) The impact of income shocks on health: evidence from cohort data, Journal of the European economic association, 7, p.1361-1399.

Adler, J.S. (2006) First in violence, deepest in dirt: homicide in Chicago, 1875-1920, Cambridge, MA: Harvard University Press.

Boudouris, J. (1974) A classification of homicides, Criminology, 11, p.525-540.

Daly, M. and Wilson, M. (1988) Homicide, New York: Aldine de Gruyter.

Eckberg, D. (2006) Crime, law enforcement, and justice, in Carter, S.B., Gartner, S.S., Haines, M. R., Omstead, A. L., Sutch, R. and Wright, G. (Eds.), Historical statistics of the United States: millennial edition, 5, Cambridge: Cambridge University Press.

Elias, N. (1994) The civiling process [1939], Oxford: Blackwell.

Fishback, P.C., Haines, M. and Kantor, S. (2007) Births, deaths, and new deal relief during the great depression, Review of economics and statistics, 89, p.1-14.

Fogel, R.W. (2004) The escape from hunger and premature death, 1700-2100, New York: Cambridge University Press.

Gerdtham, U.-G. and Ruhm, C. (2006) Deaths rise in good economic times: evidence from the OECD, Economics and human biology, 4, p.298-316.

Gould, R. (2003) Collision of wills: how ambiguity about social rank breeds conflict, Chicago: University of Chicago Press.

Granados, J.A.T. (2005) Increasing mortality during the expansions of the US economy, 19001996, International journal of epidemiology, 34, p.1194-1202.

Granados, J.A.T. and Diex Roux, A.V. (2009) Life and death during the great depression, Proceedings of the national academy of sciences, 106, p.17290-95.

Gurr, T. R. (1989) Historical trends in violent crime: Europe and the United States, in Gurr, T.R. (Ed.), Violence in America, 1, Newbury Park, CA: Sage Publications, p.21-54. 
Hosen, F.E. (1992) The great depression and the new deal: legislative acts in their entirety (1932-1946) and statistical economic data (1926-1946), Jefferson, NC: McFarland.

LaFree, G. (1998) Losing legitimacy: street crime and the decline of social institutions, Boulder: Westview.

Lane, R. (1979) Violent death in the city: suicide, accident, and murder in nineteenth-century Philadelphia, Cambridge, MA: Harvard University Press.

Lane, R. (1997) Murder in America, Columbus, OH: Ohio State University Press.

Latzer, B. (2014) Do hard times spark more crime?, Los Angeles Times, [On line] http://www. latimes.com/opinion/op-ed/la-oe-latzer-crime-economy-20140124-story.html

Latzer, B. (2016) The rise and fall of violent crime in America, New York: Encounter Books.

Lin, R.L., Shah, C.P. and Svoboda, T.J. (1995) The impact of unemployment on health: a review of the evidence, Canadian medical association journal, 153, p. 529-540.

Loftin, C., McDowall, D. and Boudouris, J. (1989) Economic change and homicide in Detroit, 1926-1979, in Gurr, T.R. (Ed.), Violence in America, 1, Newbury Park, CA: Sage Publications, p.163-177.

Monkkonen, E.H. (1986) The dangers of synthesis, American historical review, 91, p.1146-1157.

Monkkonen, E.H. (2001) Murder in New York City, Berkeley: University of California Press.

Perrott, G. and Collins, S.D. (1934) Sickness and the depression: a preliminary report upon a survey of wage-earning families in ten cities, Milbank memorial fund quarterly, 12, p.218-244.

Roth, R. (2009) American homicide, Cambridge, MA: Harvard University Press.

Ruhm, C. (2000) Are recessions good for your health?, Quarterly journal of economics, 115, p.617-650.

Ruhm, C. (2005). Mortality increases during economic downturns, International journal of epidemiology, 34, p.1206-1211.

Ruhm, C. (2015) Macroeconomics and social outcomes through a 90-year lens, International journal of epidemiology, 44, p.1490-1492.

Ruhm, C. and Black, W.E. (2002) Does drinking really decrease in bad times?, Journal of health economics, 21, p.659-678.

Stansfield, R., Williams, K.R., and Parker, K.F. (2017) Economic disadvantage and homicide: estimating temporal trends in adolescence and adulthood, Homicide studies, 21, p.59-81.

Tyler, P. (1996) Silk stockings and ballot boxes: women and politics in New Orleans, 19201965, Athens, GA: University of Georgia Press.

Vital statistics of the United States: mortality statistics, 21-41, Washington, DC: U.S. Government Printing Office, 1922-1943.

Wintemute, G. J. (1987) Firearms as a cause of death in the United States, 1920-1982, Journal of Trauma, 27, p.532-536.

Wolfgang, M (1958) Patterns of criminal homicide, New York: John Wiley.

Zahn, M.A. (1989) Homicide in the twentieth century: trends, types, and causes, in Gurr, T.R., (Ed.), Violence in America, 1, Newbury Park, CA: Sage Publications, p.216-234. 